\title{
ANALISIS BEBAN GENERATOR TERHADAP NILAI HEAT RATE DAN EFISIENSI PLTU (STUDI OBSERVASIONAL DI PT. INDOCEMENT TUNGGAL PRAKARSA, TbK P-12 TARJUN - KALIMANTAN SELATAN)
}

\author{
Muhammad Miftah Noor Rizca ${ }^{1)}$, Qomariyatus Sholihah ${ }^{2)}$, Sigit Mujiarto ${ }^{3)}$ \\ 1) Program Studi Teknik Mesin, Fakultas Teknik Universitas Lambung Mangkurat \\ JL. Akhmad Yani Km.36 Banjarbaru, Kalimantan Selatan,70714. \\ 2) Program Studi Teknik Industri, Fakultas Teknik Universitas Brawijaya \\ JL. MT. Haryono Malang Jawa Timur \\ ${ }^{3)}$ Program Studi Teknik Otomotif, Politeknik Negeri Banjarmasin, \\ JL. Hasan Basry, Banjarmasin, Kalimantan Selatan, 70123. \\ E-mail: muhammadmiftah1997@gmail.com,
}

\begin{abstract}
Heat rate is a measure of the reliability of a generating unit and as the amount of fuel energy required to produce $1 \mathrm{kWh}$ of electrical energy. This study aimed to generator load analysis on the value of heat rate, specific coal consumption and the efficiency of the plant. Heat rate, specific coal consumption and power plant efficiency can be determined by knowing the proximate coal analysis, parameter data from the control room, determine the heat value of coal, power and efficiency of the auxiliary units, NPHR, SCC, the efficiency of the boiler, turbine and power plant. From the data processing are obtained graph generator load to NPHR, SCC and efficiency of the plant. From the calculations, the highest value NPHR of $3580.77 \mathrm{kcal} / \mathrm{kWh}$ when the load of $29.86 \mathrm{MW}$, the highest value of SCC of $0.60 \mathrm{~kg} / \mathrm{kWh}$ when the load is $29.86 \mathrm{MW}$ power plant and the highest efficiency of $33.54 \%$ when the load 47 , $8 \mathrm{MW}$. So the higher the value of the generator load NPHR and SCC will be smaller, while efficient the power plant will increase.
\end{abstract}

Keywords : Heat Rate, Power Plant, Coal, NPHR, SCC

\section{PENDAHULUAN}

Kawasan industri memiliki peran strategis dalam mendorong pertumbuhan ekonomi nasional. Kementerian Perindustrian telah merevisi Peraturan Menteri Perindustrian No. 03 Tahun 2005 menjadi No. 620 Tahun 2012 Tentang Objek Vital Nasional Sektor Industri. Pembangkit listrik adalah bagian dari alat industri yang dipakai untuk memproduksi dan membangkitkan tenaga listrik dari berbagai sumber tenaga, seperti PLTU, PLTN, PLTA, PLTS, PLTD dan lain sebagainya. Pembangkit listrik tenaga uap (PLTU) adalah pembangkit yang mengandalkan energi kinetik dari uap untuk menghasilkan energi listrik. Bentuk utama dari pembangkit listrik jenis ini adalah generator yang dihubungkan ke turbin yang digerakkan oleh tenaga kinetik dari uap panas kering. Pembangkit Listrik Tenaga Uap (PLTU) menggunakan bahan bakar batubara dan diharapkan mempunyai unjuk kerja yang optimal karena lebih ekonomis dibanding dengan bahan bakar minyak sehingga dapat dioperasikan sehemat mungkin.

Efisiensi atau unjuk kerja Pembangkit Listrik Tenaga Uap (PLTU) meliputi: Heat Rate adalah kalor yang dibutuhkan untuk menghasilkan satu KWh, Efisiensi Boiler, TurbinGenerator, UAT (Unit Auxiliary Transformer) atau pemakaian listrik untuk keperluan 
sendiri. Power plant ITP P-12 Tarjun dirancang untuk memenuhi kebutuhan tenaga listrik bagi cement plant dan fasilitas pendukungnya dengan besar beban sesuai dengan kebutuhan dari pemakaian peralatan di cement plant. Mengingat sistem pada PLTU berbeda-beda pada tiap perusahaan, pada PLTU PT.ITP sistemnya masih menganut sistem yang lama, yaitu belum adanya sistem reducer pada supply bahan bakar batubara. Nilai heat rate PLTU PT.ITP adalah sebesar 11712,98 kJ/kWh dengan efisiensi 30\%, sedangkan kebutuhan untuk memenuhi unit auxiliary mencapai $5,5 \%$ dengan tegangan $400 \mathrm{v}$ dan $6,6 \mathrm{kV}$.

Mengingat umur dari PLTU PT. ITP yang hampir mencapai 20 tahun beroperasi terus menerus, pastinya akan menyebabkan berkurangnya keandalan serta umur pakainya, hal ini berkaitan langsung dengan nilai heat rate yang akan semakin meningkat dengan semakin bertambah umur suatu pembangkit listrik namun berbanding terbalik dengan efisiensinya, efisiensi akan semakin menurun dengan bertambahnya umur pembangkit listrik. Hasil dari observasi di lapangan terdapat bahwa fluktuatifnya besar beban mempengaruhi efisiensi dari PLTU sebesar 1\% - 6\% dari wawancara staff PLTU PT. ITP. Jika efisiensi pembangkit semakin rendah, maka biaya opersiaonal yang dibutuhkan akan semakin mahal. Oleh karena itu penulis tertarik untuk mengetahui bagaimana analisis beban generator terhadap nilai heat rate dan efisiensi PLTU PT. Indocement Tunggal Prakarsa, Tbk P-12 Tarjun Kalimantan Selatan.

\section{TINJAUAN PUSTAKA}

\section{Siklus Rankine Ideal}

Siklus rankine ideal meurpakan siklus termodinamika yang mengubah panas menjadi kerja. Panas disuplai secara eksternal pada aliran tertutup, yang biasanya menggunakan air sebagai fluida yang bergerak.

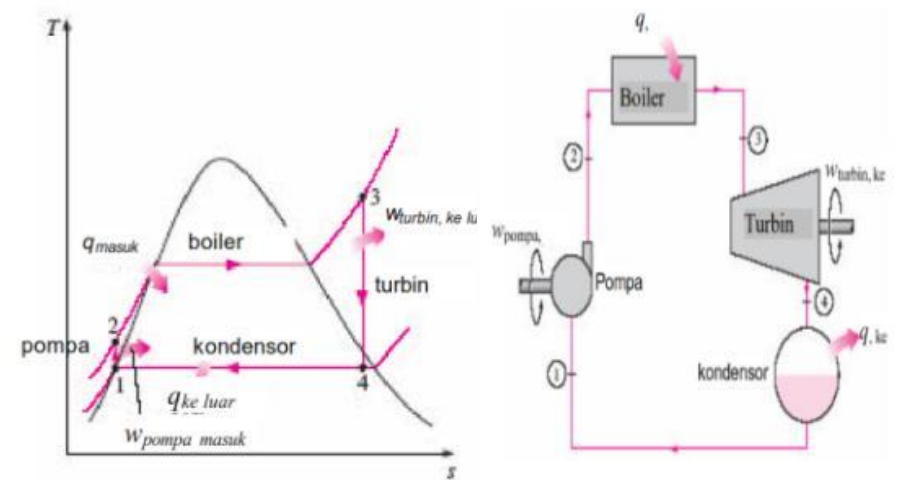

Gambar 1. Siklus Rankine Ideal

Siklus rankine memiliki 4 tahapan proses, berikut adalah tahapan dari siklus rankine:

1. Proses 1-2, merupakam proses kompresi oleh pompa terhadap cairan jenuh 
2. Proses 2-3, merupakan proses penambahan panas dalam boiler

3. Proses 3-4, merupakan proses ekspansi di dalam turbin

4. Proses 4-1, merupakan proses keluarnya panas yang terjadi di dalam condenser

Dari siklus rankine di dapat rumusan sebagai berikut:

- Penambahan Panas $\left(\mathrm{q}_{\text {in }}\right)$

$\mathrm{q}_{\mathrm{in}}=\mathrm{h}_{3}-\mathrm{h}_{2}$

- $\operatorname{Kerja~Turbin}\left(\mathrm{W}_{\mathrm{T}}\right)$

$\mathrm{W}_{\mathrm{T}}=\mathrm{h}_{3}-\mathrm{h}_{4}$

- Pelepasan Panas ( $\left.\mathrm{q}_{\text {out }}\right)$

$\mathrm{q}_{\text {out }}=\mathrm{h}_{4}-\mathrm{h}_{1}$

- Kerja Pompa (WP)

$\mathrm{W}_{\mathrm{P}}=\mathrm{h}_{2}-\mathrm{h}_{1}$

- $\operatorname{Kerja} \operatorname{Bersih}\left(\mathrm{W}_{\text {net }}\right)$

$\mathrm{W}_{\text {net }}=\left(\mathrm{h}_{3}-\mathrm{h}_{4}\right)-\left(\mathrm{h}_{2}-\mathrm{h}_{1}\right)$

- Efisiensi Thermal ( $\left.\eta_{\text {th }}\right)$

$$
\eta_{\mathrm{th}}=\frac{W_{\text {net }}}{q_{\text {in }}}=\left(\frac{\left(h_{3}-h_{4}\right)-\left(h_{2}-h_{1}\right)}{\left(h_{3}-h_{2}\right)}\right)
$$

\section{Beban Generator}

Beban generator atau daya listrik merupakan jumlah energi yang digunakan untuk melakukan kerja atau usaha dinyatakan dalam satuan $\mathrm{kW}$. Beban dikategorikan menurut konsumen penggunanya, misalnya sebagai berikut:

- $\quad$ Pemukiman, perkantoran dan pelayanan publik

- $\quad$ Industri ringan dan Industri berat

Proses kenaikan beban ditandai dengan kenaikan produksi listrik yang harus disediakan oleh generator. Proses ini dimulai dengan penambahan jumlah pembakaran bahan bakar di ruang bakar, meningkatnya kebutuhan air demin, meningkatnya produksi uap yang disalurkan ke dalam turbin uap dan meningkatnya kemampuan kondenser dalam mengkondensasikan uap tersebut. Khusus untuk proses penambahan uap yang masuk ke dalam turbin yang diatur jumlahnya oleh pembukaan Governor valve. Secara logika, bila semakin banyak uap yang masuk kedalam turbin maka putaran turbin akan bertambah yang akan mengakibatkan putaran generator meningkat.

\section{Bahan Bakar Batubara}


Batubara adalah salah satu sumber energi di dunia. Meningkatnya konsumsi batubara dunia tidak terlepas dari pesatnya permintaan energi dunia dimana batubara merupakan pemasok energi kedua terbesar setelah minyak.

a. Klasifikasi Batubara

Klasifikasi batubara ini mencakup keadaan metamorphosis yang paling rendah, sampai tinggi antara lain:

- Antrasit

- Bitumin

- Subbitumin

- Lignit

b. Kualitas Batubara

Batubara memiliki ciri fisik berupa warna hitam kusam, gores hitam, mudah pecah. Dari penelitian yang dilakukan berdasarkan analisis laboratorium didapatkan kualitas batubara, yaitu:

Tabel 1. Kualitas Batubara berdasarkan Hasil Analisis Laboratorium

\begin{tabular}{|l|l|l|}
\hline Kualitas & Rata-Rata (\%) & Kisaran (\%) \\
\hline Total Moisture & 23,59 & $19,88-30,00$ \\
\hline Inherent Moisture & 14,42 & $12,00-15,20$ \\
\hline Ash & 1,75 & $0,30-7,90$ \\
\hline Total Sulphur & 0,13 & $0,09-0,34$ \\
\hline Volatile Meter & 43,48 & $40,50-48,70$ \\
\hline Fixed Carbon & 40,84 & $38,20-58,98$ \\
\hline
\end{tabular}

c. Proses Pembakaran Batubara

Ukuran dari batubara diperkecil dengan menggunakan mesin penghancur dan disimpan di dalam coal bunker dan akan dimasukkan ke dalam coal feeder sebagai pengumpan ke dalam coal mill, yang nantinya di dalam coal mill batubara akan di proses dan digunakan sebagai bahan bakar. 


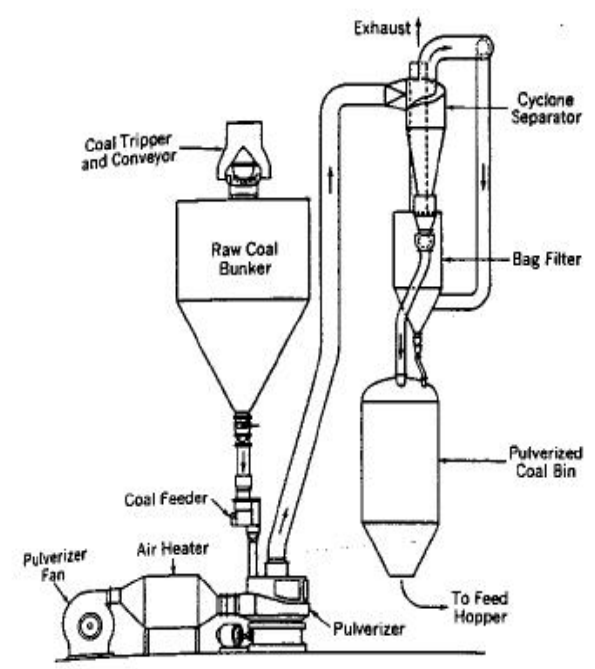

Gambar 2. Sistem Bahan Bakar Batubara

Dalam perhitungan unjuk kerja digunakan nilai Net GHV. Panas yang dihasilkan dari pembakaran batubara dapat ditentukan dengan persamaan berikut:

$$
\mathrm{QBB}_{\mathrm{BB}}=\mathrm{GHV} \times \mathrm{BB}
$$

\section{Draft Plant}

Sistem ini berfungsi mensuplai udara untuk pembakaran dan membantu aliran gas hasil pembakaran dan selanjutnya dibuang ke atmosfir melalui cerobong asap. Sistem ini terdiri dari :

1. Forced Draft Fan

2. Induced Draft Fan

3. Primary Air Fan

4. Rotary Air Heater

\section{Peralatan Bantu (Unit Auxiliary)}

Peralatan bantu merupakan peralatan yang berfungsi menunjuang kinerja peralatan utama agar dapat bekerja dengan maksimal. Dalam suatu instalasi pembangkit listrik terdapat beberapa macam pompa dan fan yang berfungsi sebagai peralatan bantu, seperti: Boiler Feed Pump, Circulating Water Pump, Induced Draft Fan, Forced Draft Fan. Untuk menggerakkan pompa dan fan tersebut diperlukan motor sebagai tenaga penggerak. Daya listrik yang diperlukan oleh motor tersebut diambil dari instalasi tersebut. Secara umum kebutuhan daya $(\mathrm{Kw})$ untuk menggerakkan motor tersebut dapat ditentukan dengan persamaan sebagai berikut: 


$$
W_{U A}=\sqrt{3} \times V \times I \times \operatorname{Cos} \alpha
$$

Sedangkan, Efisiensi Unit Auxiliary dapat ditentukan dengan persamaan berikut :

$$
\eta_{U A}=\frac{W_{\text {Generator }}-\bar{w}_{U A}}{w_{\text {Generator }}}
$$

\section{Heat Rate}

Heat rate adalah ukuran keandalan dari suatu unit pembangkit. Heat rate didefinisikan sebagai jumlah energi bahan bakar yang dibutuhkan untuk menghasilkan energi listrik sebesar $1 \mathrm{kWh}$. Heat rate juga didefinisikan sebagai jumlah dari energi bahan bakar yang dibutuhkan untuk menghasilkan sejumlah energi listrik setiap satu jam. Maka nilai heat rate dapat ditentukan dengan persamaan berikut:

$$
N P H R=\frac{Q_{B B}}{N e t G G O} \times 1000
$$

\section{Specific Coal Consumption}

Specific coal consumption (SCC) atau Konsumsi batubara spesifik merupakan pengukuran jumlah bahan bakar yang diperlukan $(\mathrm{kg})$ untuk menghasilkan daya $(\mathrm{kw})$ dalam satu jam (h) pada keadaan beban tertentu. Specific coal consumption (SCC) dapat ditentukan dengan persamaan sebagai berikut:

$$
S C C=\frac{N P H R}{G H V}
$$

\section{Boiler}

Boiler merupakan bejana bertekanan dengan bentuk ruang dan ukuran yang didesain untuk menghasilkan uap panas dengan cara melepas energi panas yang berasal dari proses pembakaran bahan bakar kemudian ditransfer ke air, sehingga menjadi uap yang bertekanan tinggi dan memiliki temperatur yang tinggi. Boiler terdiri dari beberapa komponen, yaitu:

1. Steam Drum, merupakan tangki yang berfungsi untuk menampung dan memisahkan uap yang dengan air

2. Tungku/Furnace, merupakan bagian dari boiler yang berfungsi sebagai ruang bakar.

3. Superheater, merupakan bagian dari sistem boiler yang berfungsi untuk menaikkan temperatur dan mengeringkan uap yang dihasilkan sesuai yang dibutuhkan oleh turbin.

4. Economizer, merupakan alat penukar panas yang berada di dalam sistem boiler yang berfungsi untuk memanaskan terlebih dahulu air yang masuk dari high pressure feedwater heater dengan menggunakan panas gas buang, sehingga lebih economis dan efisien 
5. Sistem penyalaan, merupakan sistem yang berfungsi untuk menyalakan burner, sistem ini terdiri dari LPG ignitor, Oil Burner, dan Coal Burner.

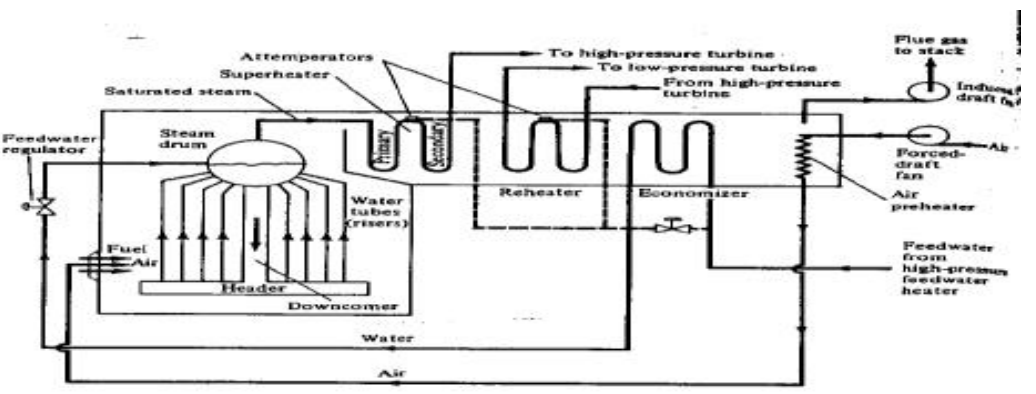

Gambar 3. Diagram Alir Boiler

Adapun formulasi untuk menghitung efisiensi boiler digunakan metode output-input, adalah sebagai berikut:

$$
\eta_{\text {Boiler }}=\frac{\left(h_{m s}-h_{f w}\right) \times f w \text { flow }}{B B \times G H V} \times 100
$$

\section{Turbin Generator}

Boiler menyuplai uap bertekanan tinggi ke dalam turbin. Aliran uap ke dalam turbin diatur oleh valve governor dan melewati serangkaian sudu tetap dan sudu gerak. Turbin Generator akan merubah energi dalam uap panas lanjut menjadi listrik. Turbin mengubah energi panas menjadi energi mekanis untuk menggerakkan generator. Selanjutnya generator akan mengubah energi mekanik menjadi energi listrik. Nilai efisiensi dari turbin dapat ditentukan dengan persamaan berikut:

$$
\eta_{\text {Turbin }}=\frac{860}{\left(\frac{m s f l o w \times\left(h_{m s}-h_{f w}\right)}{\text { Net } G G O}\right) \times 1000} \times 100
$$

\section{Efisiensi PLTU}

Efisiensi PLTU merupakan kemampuan dari PLTU untuk menghasilkan panas, panas tersebut digunakan untuk memutar turbin yang dikopel dengan generator sehingga menjadi energi listrik. Efisiensi PLTU dapat ditentukan dengan persamaan berikut:

$$
\eta_{P L T U}=\eta_{\text {Turbin }} \times \eta_{\text {Boiler }} \times \eta_{U A}
$$




\section{METODELOGI PENELITIAN}

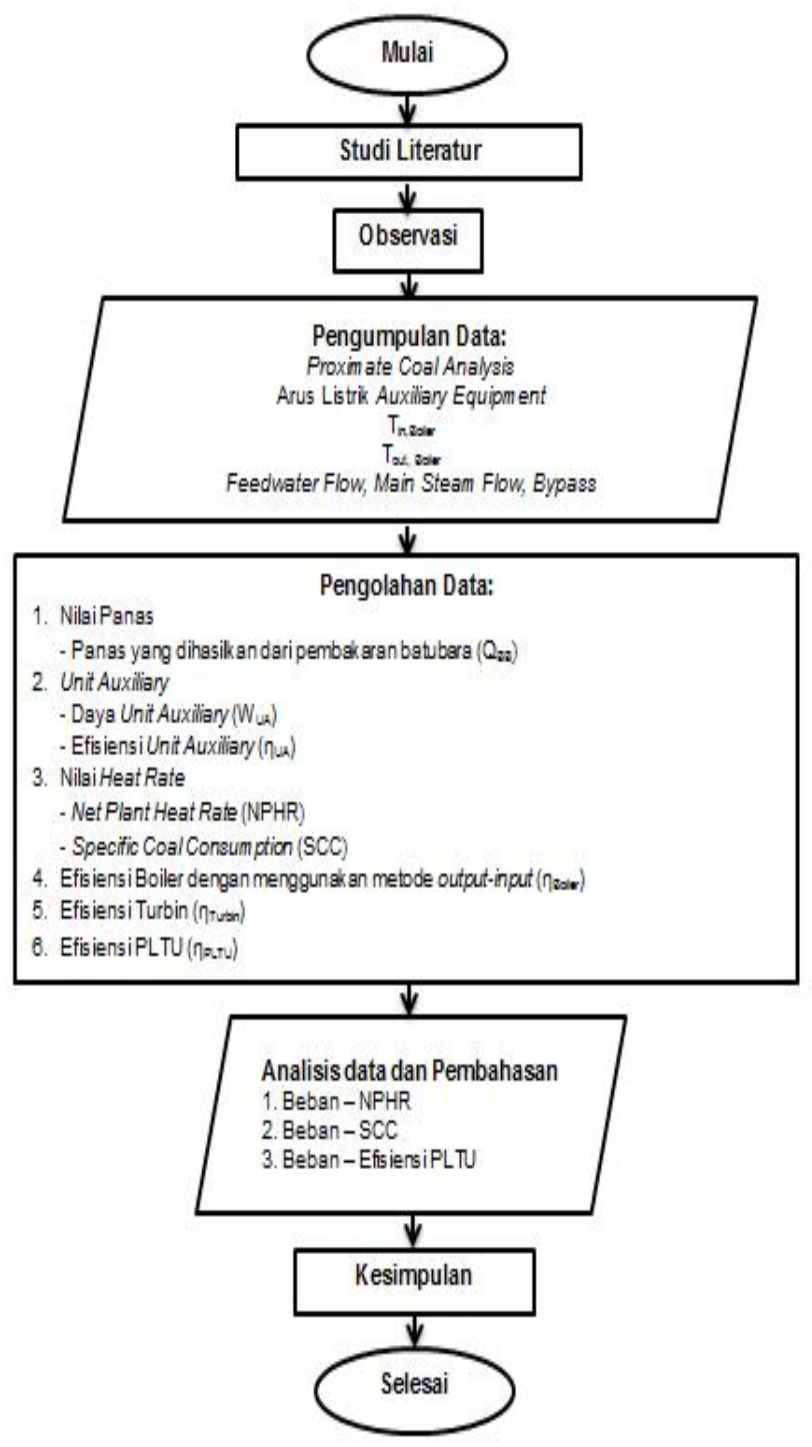

Gambar 4. Flow chart Penelitian

Prosedur penelitian adalah sebagai berikut:

1. Pengambilan data batubara (Proximate Analysis)

2. Pengambilan data pengamatan (Beban, $\mathrm{T}_{\text {in,Boiler }}, \mathrm{T}_{\text {out }}$ Boiler , Arus unit auxiliary)

3. Menentukan nilai panas yang dihasilkan dari pembakaran batubara $\left(\mathrm{Q}_{\mathrm{BB}}\right)$

4. Menentukan daya dan efisiensi unit auxiliary

5. Menentukan NPHR

6. Menentukan nilai Specific Coal Consumption (SCC) 
7. Menentukan Efisiensi Boiler dengan menggunakan metode output-input

8. Menentukan Efisiensi Turbin

9. Menentukan Efisiensi PLTU

\section{HASIL DAN PEMBAHASAN}

\section{Analisis Beban Generator terhadap NPHR}

Dari hasil perhitungan analisis beban generator terhadap NPHR, maka dapat diperoleh garfik hubungan analisis beban generator terhadap nilai NPHR sebagai berikut:

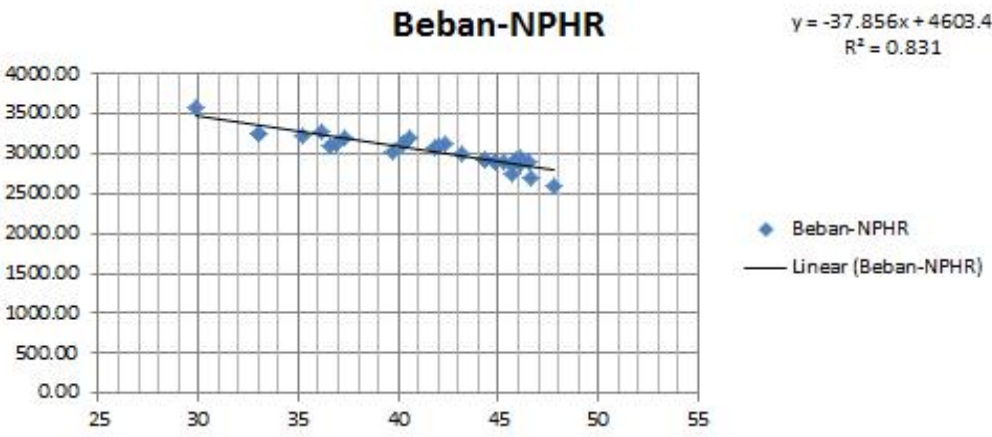

Gambar 5. Grafik Analisis Beban Generator terhadap NPHR

Dari grafik 4.1 dapat dilihat hubungan korelasi linear grafik analisis beban generator terhadap NPHR adalah berbanding terbalik, semakin besar beban maka NPHR akan semakin kecil. Nilai tertinggi NPHR adalah sebesar $3580,77 \mathrm{kcal} / \mathrm{kWh}$ pada saat beban 29,86 MW, Sedangkan nilai terkecil NPHR adalah 2594,57 kcal/kWh pada saat beban 47,8 MW. Besarnya nilai NPHR pada saat beban generator rendah disebabkan karena pada saat beban generator rendah jumlah uap masuk yang diperlukan oleh turbin lebih sedikit daripada saat beban generator tinggi, sehingga menyebabkan sedikitnya uap keluaran dari turbin yang digunakan sebagai fluida pemanas pada LP heater, Deaerator dan HP heater tidak akan bekerja secara maksimal.

Tidak maksimalnya kerja dari heater ini menyebabkan temperatur air umpan sebelum masuk ke dalam boiler kurang cukup tinggi, sehingga menyebabkan kinerja boiler lebih berat, beratnya kerja boiler ini akan mempengaruhi dari banyaknya jumlah batubara yang digunakan untuk memanaskan air hingga berubah menjadi uap untuk memutar turbin. Besarnya nilai GHV juga mempengaruhi terhadap nilai NPHR, karena semakin rendah GHV maka kualitas batubara akan semakin rendah dan secara otomatis akan menambah pemakaian batubara untuk mencapai kalori yang diperlukan untuk membangkitkan $1 \mathrm{kWh}$.

Dari grafik 4.1 juga dapat dilihat nilai NPHR terbaik hanya mencapai 2594,57 $\mathrm{kcal} / \mathrm{kWh}$, hal ini menunjukkan bahwa nilai NPHR sudah mulai meningkat daripada nilai 
NPHR standar design dari PLTU PT.ITP yaitu sebesar $2512 \mathrm{kcal} / \mathrm{kWh}$ pada beban 48,4 MW (lampiran 1). Meningkatnya nilai NPHR ini disebabkan dikarenakan faktor umur (life time) dari PLTU PT.ITP yang sudah hampir mencapai 20 tahun beroperasi.

\section{Analisis Beban Generator terhadap SCC}

Dari hasil perhitungan analisis beban generator terhadap SCC, maka dapat diperoleh garfik hubungan analisis beban generator terhadap nilai SCC sebagai berikut:

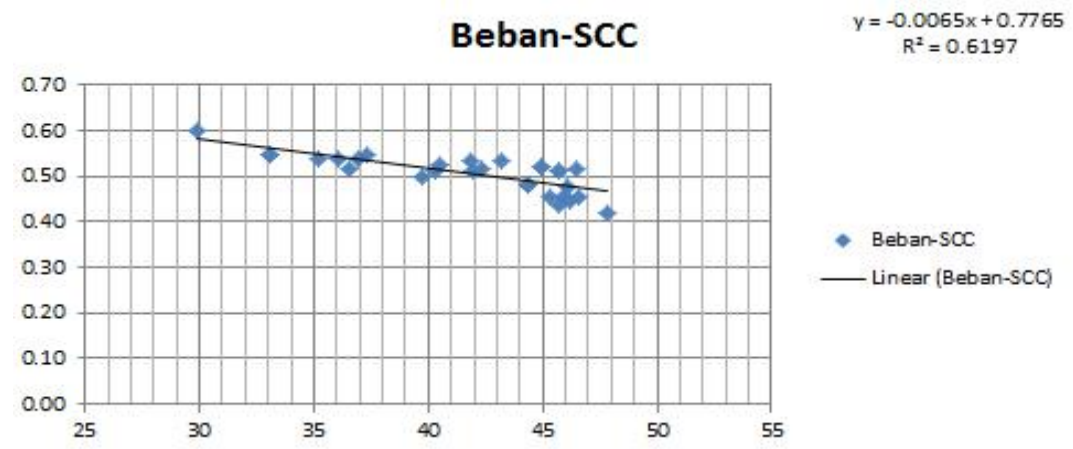

Gambar 6. Grafik Analisis Beban Generator terhadap SCC

Dari grafik 4.2 di atas dapat dilihat hubungan korelasi dari garis linear grafik analisis beban generator terhadap SCC adalah berbanding terbalik, semakin besar beban maka SCC akan semakin kecil. Nilai tertinggi SCC adalah sebesar $0,60 \mathrm{~kg} / \mathrm{kWh}$ pada saat beban 29,86 MW, Sedangkan nilai terkecil SCC adalah $0,42 \mathrm{~kg} / \mathrm{kWh}$ pada saat beban 47,8 MW. Besarnya nilai SCC pada saat beban generator rendah juga disebabkan karena pada saat beban generator rendah jumlah uap masuk yang diperlukan oleh turbin lebih sedikit daripada saat beban generator tinggi, sedikitnya uap keluaran dari turbin yang digunakan sebagai fluida pemanas pada LP heater, Deaerator dan HP heater tidak akan bekerja secara maksimal.

Tidak maksimalnya kerja dari heater ini menyebabkan temperatur air umpan sebelum masuk ke dalam boiler kurang cukup tinggi, sehingga menyebabkan kinerja boiler lebih berat, beratnya kerja boiler ini akan mempengaruhi dari banyaknya jumlah batubara yang digunakan untuk memanaskan air hingga berubah menjadi uap untuk memutar turbin. Besarnya nilai GHV juga mempengaruhi terhadap nilai SCC, karena semakin rendah GHV maka kualitas batubara akan semakin rendah dan secara otomatis akan menambah pemakaian batubara untuk mencapai kalori yang diperlukan.

\section{Analisis Beban Generator terhadap Efisiensi PLTU}


Dari hasil perhitungan analisis beban generator terhadap Efisiensi PLTU, maka dapat diperoleh garfik hubungan analisis beban generator terhadap nilai Efisiensi PLTU sebagai berikut:

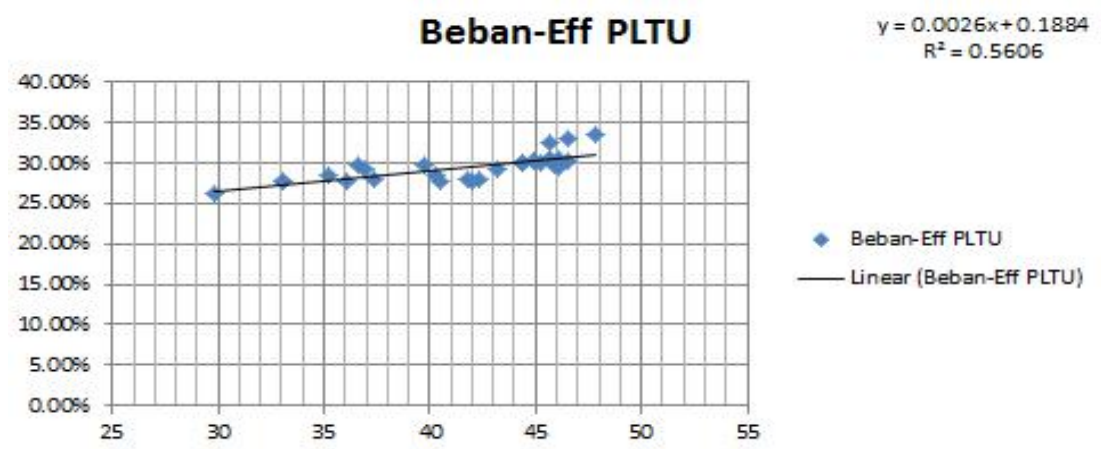

Gambar 7. Grafik Analisis Beban Generator terhadap Efisiensi PLTU

Dari grafik 4.3 di atas dapat dilihat hubungan korelasi dari garis linear grafik analisis beban generator terhadap efisiensi PLTU adalah berbanding lurus, semakin besar beban maka efisiensi PLTU akan semakin besar. Efisiensi PLTU tertinggi adalah sebesar 33,54\% pada saat beban 47,8 MW, sedangkan efisiensi PLTU terkecil adalah 26,27\% pada saat beban 29,86 MW. Kecilnya nilai efisiensi PLTU ini disebabkan oleh beberapa faktor, yaitu adalah sebagai berikut:

1. Jumlah pemakaian dari unit auxiliary akan mempengaruhi efisiensi PLTU, hal ini karena sumber energi unit auxiliary berasal dari beban generator yang dibangkitkan. Pada saat beban generator rendah ditambah dengan pemakain unit auxiliary, maka secara tidak langsung akan mengurangi beban generator yang dibangkitkan menjadi lebih rendah karena beban generator yang dibangkitkan digunakan untuk keperluan dari unit auxiliary sendiri.

2. Tidak maksimalnya kerja dari heater yang menyebabkan kurang tingginya temperatur masuk air umpan ke dalam boiler. Pada saat beban generator rendah jumlah uap masuk yang diperlukan oleh turbin lebih sedikit daripada saat beban generator tinggi, sedikitnya uap keluaran dari turbin yang digunakan sebagai fluida pemanas pada LP heater, Deaerator dan HP heater tidak akan bekerja secara maksimal. Tidak maksimalnya kerja dari heater ini menyebabkan temperatur air umpan sebelum masuk ke dalam boiler kurang cukup tinggi, sehingga menyebabkan kinerja boiler lebih berat dan akan mempengaruhi dari banyaknya jumlah batubara yang digunakan untuk memanaskan air hingga berubah menjadi uap untuk memutar turbin. 
3. Banyaknya uap yang melewati jalur bypass (tidak masuk ke dalam turbin), pada saat beban rendah kapasitas uap yang dibutuhkan turbin akan lebih sedikit daripada saat beban tinggi, hal ini akan menyebabkan banyaknya uap yang melewati jalur bypass, uap yang melewati jalur bypass ini akan masuk dan didinginkan langsung ke dalam kondensor tanpa dimanfaatkan

\section{KESIMPULAN}

1. Nilai tertinggi NPHR adalah sebesar $3580,77 \mathrm{kcal} / \mathrm{kWh}$ pada saat beban 29,86 MW, Sedangkan nilai terkecil NPHR adalah $2594,57 \mathrm{kcal} / \mathrm{kWh}$ pada saat beban 47,8 MW. Semakin besar beban generator maka NPHR akan semakin kecil dan Nilai NPHR sudah melebihi nilai NPHR standar design dari PLTU PT.ITP yaitu sebesar $2512 \mathrm{kcal} / \mathrm{kWH}$ yang disebabkan karena faktor umur (life time) dari PLTU PT.ITP yang sudah hampir mencapai 20 tahun beroperasi.

2. Nilai tertinggi SCC adalah sebesar $0,60 \mathrm{~kg} / \mathrm{kWh}$ pada saat beban $29,86 \mathrm{MW}$, Sedangkan nilai terkecil SCC adalah $0,42 \mathrm{~kg} / \mathrm{kWh}$ pada saat beban 47,8 MW. Semakin besar beban generator maka SCC akan semakin kecil.

3. Efisiensi PLTU tertinggi adalah sebesar 33,54\% pada saat beban 47,8 MW, efisiensi PLTU terkecil adalah 26,27\% pada saat beban 29,86 MW. Pengaruh beban generator terhadap efisiensi adalah sebesar 56,06\%, maka dari itu PLTU akan semakin efisien dan optimal jika dioperasikan pada beban generator tinggi.

\section{REFERENSI}

1. El-Wakil, M. M. 1992. Instalasi Pembangkit Daya. Jakarta: Erlangga.

2. Hendroyono.A,. Sahid,. Dwiana H. 2014. Analisa Heat Rate dengan Variasi Beban pada PLTU Paiton Unit 9. Jurnal Teknik Energi Vol 10 No.1;23-28. Semarang: Politeknik Semarang Program Studi Teknik Konversi Energi, Jurusan Teknik Mesin.

3. Nag, P.K. 2008. Power Plant Engineering Higher Education 3rd Edition. New York: Mc-Graw-Hill Book Company.

4. Sholihah, Qomariyatus. 2014. K3 (Keselamatan dan Kesehatan Kerja) Batubara Malang:UB Press. ISBN: 978-602-203-667-8.

5. Sugiantoro, Bambang. 2008. Metode Analisis Energy Perhitungan Metode Direct and Indirect (Heat Rate/Tara Kalor) Bahan Bakar Batubara dan Pengaruhnya pada Performance Sistem Uap. Jurnal. Intuisi Teknologi dan Seni. ISSN 1978-2947

6. Sunyoto, dkk. 2008. Teknik Mesin Industri, Jilid 3. Jakarta:Departemen Pendidikan Nasional. ISBN: 978-979-060-085-0. 